\title{
CONFIRMATION OF NATURAL HYBRID OF SHOREA LEPROSULA AND S. CURTISII IN PASIR PANJANG FOREST RESERVE, NEGERI SEMBILAN, MALAYSIA
}

\author{
Ng KKS*, Lee SL, Tnah LH, Ng CH, Lee CT, Nurul-Farhanah Z \& Amelia A \\ Forest Research Institute Malaysia, 52109 Kepong, Selangor, Malaysia \\ *kevin@frim.gov.my \\ Submitted and accepted: December 2019
}

This study established natural interspecific hybridisation in a particularly important tropical timber group, Shorea. A mature putative hybrid of Shorea leprosula and S. curtisii discovered in Pasir Panjang Forest Reserve, Negeri Sembilan showed intermediate morphological features when compared with S. leprosula and S. curtisii. Molecular analyses using PgiC gene region further reinforced the hypothesis of hybridisation between $S$. leprosula and S. curtisii.

\section{INTRODUCTION}

The general flowering of dipterocarps in the South-East Asian tropical rainforest is a phenomenon that occurs intermittently between 2 and 10 years (Appanah 1993). Such masting event triggers the burst of floral-feeding insect populations (namely, thrips, hoppers, bees and beetles) that facilitate intraspecific breeding and the possibility of interspecific gene-exchange or natural hybridisation (Appanah 1985, Appanah \& Chan 1981). Although the success rate of natural hybridisation is unknown, putative natural hybrids of dipterocarps, particularly of Shorea genus have been frequently reported (Kaur et al. 1978, Somego 1978, Jong \& Kaur 1979, Chan 1981, Ashton 1982).

The occurrences of putative natural hybrids of Shorea leprosula and S. curtisii were first reported at Bukit Lagong Forest Reserve, Kepong, Malaysia and Bukit Timah Nature Reserve, Singapore (Ashton 1982). Several adult trees and saplings were found to be morphologically intermediate between the two parent types at the ecotonal zones of these two species. However, the two putative hybrids at Bukit Lagong Forest Reserve were found dead in 1998, believed to be struck by lightning and have never been verified as the true natural hybrids. Nevertheless, the putative hybrids discovered at Bukit Timah Nature Reserve were recently verified based on morphological and molecular evidences (Kamiya et al. 2011).
On the $8^{\text {th }}$ November 2017 , the State Forest Department of Negeri Sembilan reported for the first time the presence of a mature putative natural hybrid of S. leprosula and S. curtisii in Compartment 7, Pasir Panjang Forest Reserve, Negeri Sembilan. This study intended to verify the putative hybrid using morphological and molecular methods.

\section{MATERIALS AND METHODS}

On the $18^{\text {th }}$ January 2018 , guided by staff of the State Forest Department of Negeri Sembilan, leaf tissue was collected in Compartment 7, Pasir Panjang Forest Reserve from one mature putative hybrid (DNA ID 14946; Table 1, Figure 1). Samples from two other suspected hybrid seedlings nearby the mature putative hybrid were also collected (DNA IDs 14950 \& 14951; Table 1, Figure 1). Six mature trees each of $S$. leprosula (DNA IDs 14955-14960) and S. curtisii (DNA IDs 14947-14949 and 14952-14954) were also collected around the mature putative hybrid to serve as controls.

Total genomic DNA was extracted from leaf tissues using modified CTAB method of Murray and Thompson (1980) and the DNA obtained was further purified using High Pure Template Preparation Kit. To determine species-specific nucleotide substitutions, PgiC nuclear region described by Kamiya et al. (2011) was used for 
Table 1 The sample details of putative hybrids, Shorea leprosula and S. curtisii collected from Compartment 7, Pasir Panjang Forest Reserve, Negeri Sembilan

\begin{tabular}{llcc}
\hline DNA ID & Species & DBH $(\mathrm{cm})$ & GPS Coordinate \\
\hline 14946 & Putative hybrid & 77 & N2.41662 E101.94635 \\
14950 & Putative hybrid & 2 & N2.41658 E101.94625 \\
14951 & Putative hybrid & 1 & N2.41653 E101.94645 \\
14955 & S. leprosula & 57 & N2.41455 E101.94425 \\
14956 & S. leprosula & 54 & N2.41465 E101.94430 \\
14957 & S. leprosula & 66 & N2.41463 E101.94418 \\
14958 & S. leprosula & 61 & N2.41473 E101.94420 \\
14959 & S. leprosula & 73 & N2.41488 E101.94417 \\
14960 & S. leprosula & 46 & N2.41502 E101.94400 \\
14947 & S. curtisii & 59 & N2.41667 E101.94635 \\
14948 & S. curtisii & 50 & N2.41675 E101.94625 \\
14949 & S. curtisii & 29 & N2.41687 E101.94628 \\
14952 & S. curtisii & 49 & N2.41668 E101.94648 \\
14953 & S. curtisii & 30 & N2.41675 E101.94653 \\
14954 & S. curtisii & 100 & N2.41675 E101.94653 \\
\hline
\end{tabular}
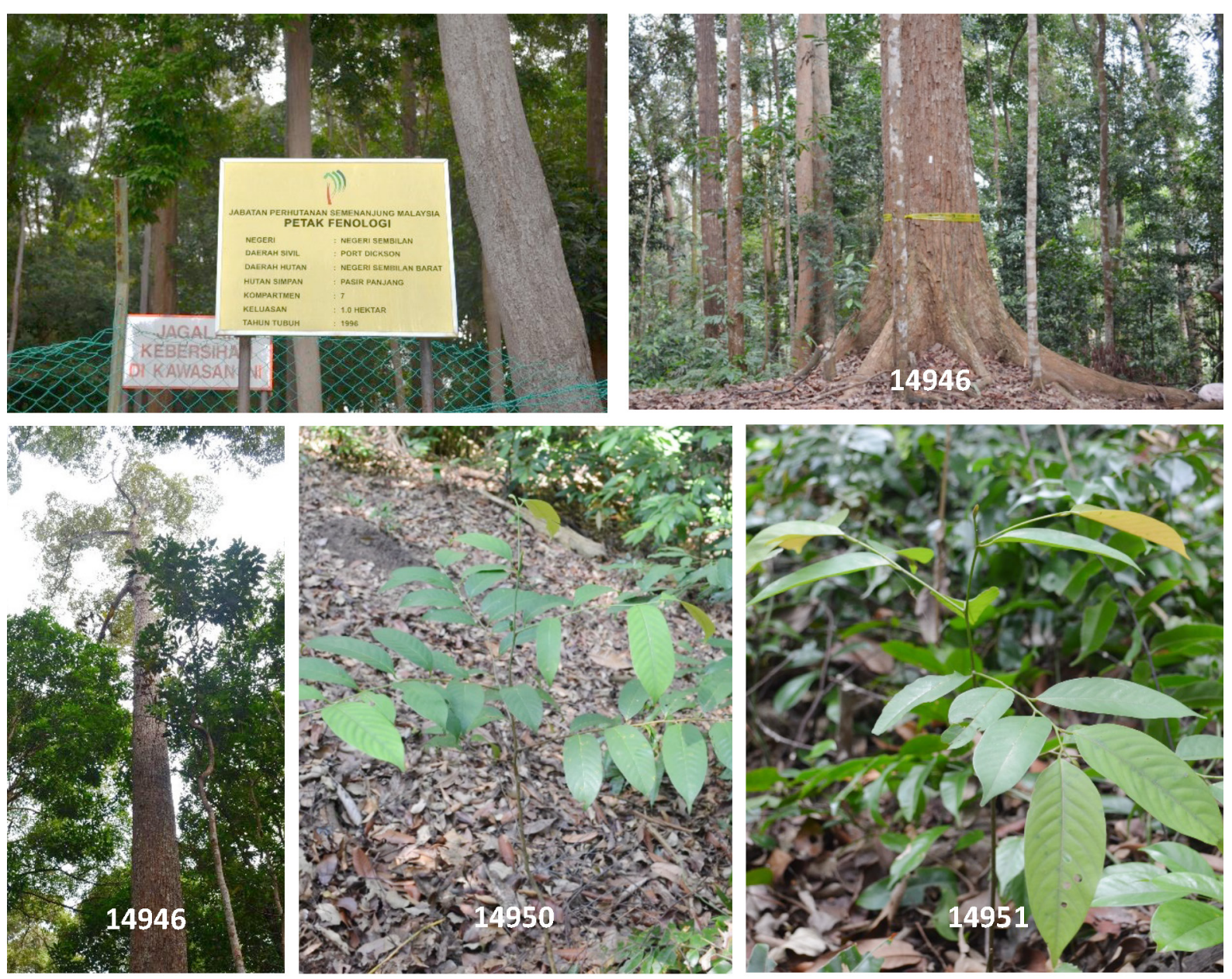

Figure 1 Sample collection of a mature putative hybrid (14946) and two putative hybrid seedlings (14950 \& 14951) from Compartment 7, Pasir Panjang Forest Reserve, Negeri Sembilan 
polymerase chain reaction and direct DNA sequencing on all the samples were carried out.

\section{RESULTS AND DISCUSSION}

Mature putative hybrid (Figure 2B) had lanceolate leaves with cuneate leaf base similar to $S$. curtisii (Figure 2A), a tomentose abaxial leaf surface like S. leprosula (Figure 2C), and linear-to ellipticoblong stipules, suggesting it to be intermediate between the two parental species. Similar leaf morphological characters of putative hybrid have been previously reported by Kamiya et al. (2011) in Bukit Timah Nature Reserve, Singapore. For the two putative hybrid seedlings, the leaves were morphologically similar to $S$. curtisii, but were broader than typical $S$. curtisii and more alike to S. leprosula.

PgiC region showed nine nucleotide positions that can be used to differentiate $S$. leprosula and S. curtisii (positions 110, 120, 125, 137, 200, 494, 646, 684 \& 758; Table 2, Figure 3). In comparison with control samples, putative hybrid 14946 contained both the species-specific mutations found in S. leprosula and S. curtisii across all the nine nucleotide positions, whereas for putative hybrids 14950 and 14951, the nine nucleotide positions were exactly similar to S. curtisii. Based on this findings, we conclude that putative hybrid 14946 is indeed a hybrid of $S$. leprosula and S. curtisii, whereas 14950 and 14951 are S. curtisii. Subsequently, the presence of a mature natural hybrid of $S$. leprosula and $S$. curtisii in Compartment 7, Pasir Panjang Forest Reserve, Negeri Sembilan further confirmed previous finding suggesting the occurrence of interspecific hybridisation in Shorea species (Kamiya et al. 2011). Interspecific hybridisation can introduce new alleles to a species and thus affects its evolution. In the mixed dipterocarp forests, $S$. curtisii trees dominate the ridges of hill forests whereas $S$. leprosula is commonly found in the lowland forests. Thus, the natural hybrids may represent a source of novel diversity that may have adaptive potential which may warrant to be conserved. Additional studies are necessary to evaluate the evolutionary significance of natural interspecific hybridisation among dipterocarps.

\section{ACKNOWLEDGEMENTS}

We would like to thank the State Forest Department of Negeri Sembilan for their kind cooperation and assistance in showing us the


Figure 2 Leaf morphological characters of Shorea curtisii (A), mature putative hybrid of S. leprosula and S. curtisii (B) and S. leprosula (C) 
Table 2 Species-specific nucleotide positions in PgiC region for S. leprosula, S. curtisii and putative hybrids

\begin{tabular}{|c|c|c|c|c|c|c|c|c|c|c|}
\hline \multirow[t]{2}{*}{ Species (DNA ID) } & \multicolumn{9}{|c|}{ Nucleotide position } & \multirow{2}{*}{ Conclusion } \\
\hline & 110 & 120 & 125 & 137 & 200 & 494 & 646 & 684 & 758 & \\
\hline S. leprosula (14955) & G & A & C & C & $\mathrm{T}$ & G & $\mathrm{T}$ & $\mathrm{C}$ & $\mathrm{C}$ & Control \\
\hline S. leprosula (14956) & G & A & $\mathrm{C}$ & $\mathrm{C}$ & $\mathrm{T}$ & G & $\mathrm{T}$ & $\mathrm{C}$ & $\mathrm{C}$ & Control \\
\hline S. leprosula (14957) & G & A & $\mathrm{C}$ & C & $\mathrm{T}$ & G & $\mathrm{T}$ & $\mathrm{C}$ & $\mathrm{C}$ & Control \\
\hline S. leprosula (14958) & G & A & C & C & $\mathrm{T}$ & G & $\mathrm{T}$ & $\mathrm{C}$ & $\mathrm{C}$ & Control \\
\hline S. leprosula (14959) & G & A & $\mathrm{C}$ & C & $\mathrm{T}$ & G & $\mathrm{T}$ & $\mathrm{C}$ & $\mathrm{C}$ & Control \\
\hline S. leprosula (14960) & G & A & C & $\mathrm{C}$ & $\mathrm{T}$ & G & $\mathrm{T}$ & $\mathrm{C}$ & $\mathrm{C}$ & Control \\
\hline S. curtisii (14947) & $\mathrm{T}$ & $\mathrm{T}$ & $\mathrm{T}$ & A & G & A & $\mathrm{C}$ & $\mathrm{T}$ & A & Control \\
\hline S. curtisii (14948) & $\mathrm{T}$ & $\mathrm{T}$ & $\mathrm{T}$ & A & G & A & $\mathrm{C}$ & $\mathrm{T}$ & A & Control \\
\hline S. curtisii (14949) & $\mathrm{T}$ & $\mathrm{T}$ & $\mathrm{T}$ & $\mathrm{A}$ & G & A & C & $\mathrm{T}$ & A & Control \\
\hline S. curtisii (14952) & $\mathrm{T}$ & $\mathrm{T}$ & $\mathrm{T}$ & A & G & A & $\mathrm{C}$ & $\mathrm{T}$ & A & Control \\
\hline S. curtisii (14953) & $\mathrm{T}$ & $\mathrm{T}$ & $\mathrm{T}$ & A & G & A & $\mathrm{C}$ & $\mathrm{T}$ & A & Control \\
\hline S. curtisii (14954) & $\mathrm{T}$ & $\mathrm{T}$ & $\mathrm{T}$ & A & G & A & $\mathrm{C}$ & $\mathrm{T}$ & A & Control \\
\hline Putative hybrid (14946) & $\mathrm{T} / \mathrm{G}$ & $\mathrm{T} / \mathrm{A}$ & $\mathrm{T} / \mathrm{C}$ & $\mathrm{A} / \mathrm{C}$ & $\mathrm{G} / \mathrm{T}$ & $\mathrm{A} / \mathrm{G}$ & $\mathrm{C} / \mathrm{T}$ & $\mathrm{T} / \mathrm{C}$ & $\mathrm{A} / \mathrm{C}$ & Hybrid \\
\hline Putative hybrid (14950) & $\mathrm{T}$ & $\mathrm{T}$ & $\mathrm{T}$ & A & G & A & $\mathrm{C}$ & $\mathrm{T}$ & A & S. curtisii \\
\hline Putative hybrid (14951) & $\mathrm{T}$ & $\mathrm{T}$ & $\mathrm{T}$ & $\mathrm{A}$ & G & $\mathrm{A}$ & C & $\mathrm{T}$ & $\mathrm{A}$ & S. curtisii \\
\hline
\end{tabular}

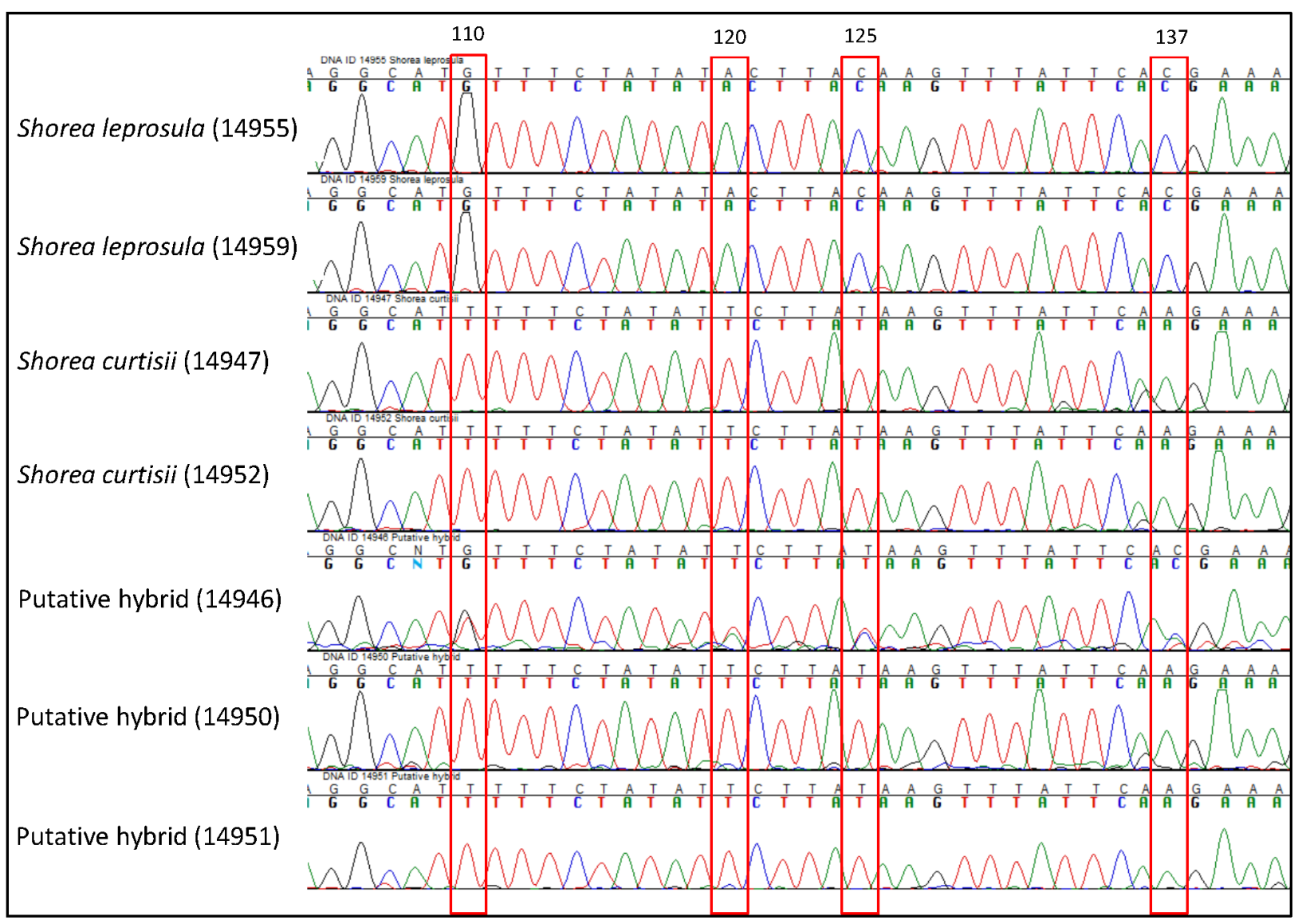

Figure 3 Example of four sequence variation positions (110, 120, 125 and 137) based on a snapshot of the electropherogram of Shorea leprosula, S. curtisii, and the putative hybrids; electropherogram of putative hybrid (14946) showed species-specific mutation found in both S. leprosula and S. curtisii (double peaks) 
location of the putative hybrids. We also want to thank Ramli P and Yasri B for their help in sample collection, and Sharifah T, Suryani CS, Ghazali $\mathrm{J}$ and Yahya $\mathrm{M}$ for their help in DNA extraction.

\section{REFERENCES}

Appanah S. 1985. General flowering in the climax rain forests of South-east Asia. Journal of Tropical Ecology 1: 225-240.

APPANAH S. 1993. Mass flowering of dipterocarp forests in the aseasonal tropics. Journal of Biosciences 18: 457-474.

APPANAH S \& Chan HT. 1981. Thrips: the pollinators of some dipterocarps. Malaysian Forester 44: 234-252.

Ashton PS. 1982. Dipterocarpaceae. Pp 237-552 in Van Steenis CGGJ (ed) Flora Malesiana I. Volume 9. Martinus Nijhoff, The Hague.

Chan HT. 1981. Reproductive biology of some Malaysian dipterocarps. III. Breeding systems. Malaysian Forester 44: 28-36.
Jong K \& KaUR A. 1979. A cytotaxonomic view of Dipterocarpaceae with some comments on polyploidy and apomixis. In Maury-Lechon G (ed) Dipterocarpaceae: Taxonomie-Phylogénie Ecologie. Paris: Memoires du Museum National d'Histoire Naturelle, serie B, Botanique 26, Editions du Museum: 41-49.

Kamiya K, Gan YY, Lum SKY, Khoo MS, Chua SC \& FaIzu NNH. 2011. Morphological and molecular evidence of natural hybridization in Shorea (Dipterocarpaceae). Tree Genetics and Genomes 7: 297-306.

Kaur A, Ha CO, Jong K, Sands Ve, Chan HT, Soepadmo E \& Ashton PS. 1978. Apomixis may be widespread among trees of the climax rain forest. Nature 271: 440-442.

Murray M \& Thompson WF. 1980. Rapid isolation of high molecular weight plant DNA. Nucleic Acids Research 8: 4321-4325.

Somego M. 1978. Cytogenetical study of Dipterocarpaceae. Malaysian Forester 41: 358-366. 